\title{
Genetic Analysis of the Resistance to Eight Anthracnose Races in the Common Bean Differential Cultivar Kaboon
}

\author{
Ana Campa, Ramón Giraldez, and Juan José Ferreira
}

First and third authors: Area de Cultivos Hortofrutícolas y Forestales, SERIDA, Apdo. 13, 33300, Villaviciosa (Asturias), Spain; and second author: Department of Biología Funcional, University of Oviedo, 33006 Oviedo, Spain.

Accepted for publication 1 February 2011.

\section{ABSTRACT}

Campa, A., Giraldez, R., and Ferreira, J. J. 2011. Genetic analysis of the resistance to eight anthracnose races in the common bean differential cultivar Kaboon. Phytopathology 101:757-764.

Resistance to the eight races $(3,7,19,31,81,449,453$, and 1545) of the pathogenic fungus Colletotrichum lindemuthianum (anthracnose) was evaluated in $\mathrm{F}_{3}$ families derived from the cross between the anthracnose differential bean cultivars Kaboon and Michelite. Molecular marker analyses were carried out in the $F_{2}$ individuals in order to map and characterize the anthracnose resistance genes or gene clusters present in Kaboon. The analysis of the combined segregations indicates that the resistance present in Kaboon against these eight anthracnose races is determined by 13 different race-specific genes grouped in three clusters.
One of these clusters, corresponding to locus Co- 1 in linkage group (LG) 1 , carries two dominant genes conferring specific resistance to races 81 and 1545 , respectively, and a gene necessary (dominant complementary gene) for the specific resistance to race 31. A second cluster, corresponding to locus $\mathrm{Co}-3 / 9$ in LG 4, carries six dominant genes conferring specific resistance to races $3,7,19,449,453$, and 1545 , respectively, and the second dominant complementary gene for the specific resistance to race 31. A third cluster of unknown location carries three dominant genes conferring specific resistance to races 449,453 , and 1545 , respectively. This is the first time that two anthracnose resistance genes with a complementary mode of action have been mapped in common bean and their relationship with previously known $\mathrm{Co}$ - resistance genes established.
Anthracnose, caused by Colletotrichum lindemuthianum, is one of the most destructive diseases of common bean (Phaseolus vulgaris L.) worldwide. The fungus is seedborne and has highly pathogenic variability. More than 100 different races of this pathogen have been described $(5,15,33,41,49)$. Identification of anthracnose races has been internationally standardized based on the disease reaction of the 12 differential common bean cultivars-Michelite, Michigan Dark Red Kidney (MDRK), Perry Marrow, Cornell 49242, Widusa, Kaboon, Mexico 222, PI207262, TO, TU, AB136 and G2333 - and named based on a binary nomenclature system (46).

Up to now, 18 anthracnose resistance loci (designated as $\mathrm{Co}$ followed by a number or a letter), at first considered as single genes conferring resistance to several anthracnose races, have been reported in common bean. Some of these loci have been located in the integrated linkage map (18,31): Co-1, probably allelic to Co- $x$ and $\mathrm{Co}-\mathrm{w}$, on linkage group (LG) $1(7,19,51)$; $\mathrm{Co}-2$ on LG $11(1,34)$; $\mathrm{Co}-3$ (Co-3/9), allelic to $\mathrm{Co}-9$, $\mathrm{Co}-y$, and $\mathrm{Co}-z$, on LG $4(6,14,20,22,40,50,51)$; Co-4 on LG $8(16,36,39)$; Co-5 on LG $7(10,16)$; Co-6, probably allelic to $C o-v$, on LG 7 (19,30,59); Co-10 on LG 4 (3,30); and Co-u, on LG 2 (21).

The characterization of the loci involved in the resistance of most anthracnose differential cultivars was at first interpreted based on the combined results of different allelism tests. Only in some cases have such resistance loci been mapped using molecular markers. From the results of allelism tests, a single dominant gene $(\mathrm{Co}-11)$ conferring resistance to race 64 has been described in the differential cultivar Michelite (25). The recessive resistance

Corresponding author: R. Giraldez; E-mail address: giraldez@uniovi.es

* The $\boldsymbol{e}$-Xtra logo stands for "electronic extra" and indicates that the online version contains two supplemental tables.

doi:10.1094/PHYTO-11-10-0296

(C) 2011 The American Phytopathological Society gene described in Michelite by Cardenas et al. (12) has been recently reinterpreted as a reverse of dominance of the Co-11 gene due to epistatic interaction with other genes (25). Co- 1 was assumed to be the only anthracnose resistance locus present in the differential cultivar MDRK (35). However, using direct mapping, Campa et al. (10) demonstrated that MDRK carries two independent anthracnose resistance loci. One of them, located in LG 1 (corresponding to the $\mathrm{Co}-1$ locus), confers resistance to race 1545 , and the other, located in LG 4 (corresponding to the Co-3/9 locus), is a cluster of at least two different genes conferring specific resistance to races 1545 and 449, respectively. From the results of allelism tests, the $C o-1$ and other unspecified complementary loci have been reported to be present in Perry Marrow and Kaboon $(12,38,44)$. The Co-2 locus is present in the differential cultivar Cornell 49242, in which it was first described as a single major gene conferring resistance to races $\alpha, \beta, \gamma$, and $\Delta$ (34). From the results of allelism tests, it was assumed that $\mathrm{Co}-1$ was the only anthracnose resistance locus present in the differential cultivar Widusa (24). Later, Alzate-Marin et al. (4), using allelism tests conducted with other anthracnose races, proposed the presence of an allele of $C o-9$ in Widusa. Rodríguez-Suárez et al. (50), using direct mapping, demonstrated the presence of two independent loci in Widusa. One of them, located in LG 4 (corresponding to the $\mathrm{Co}-3 / 9$ locus), is a cluster formed by different genes conferring specific resistance to races $65,73,102$, and 449 , respectively, and the other, located in a position independent from the $\mathrm{Co}-3 / 9$ cluster (probably corresponding to $\mathrm{Co}-1$ ), confers resistance to race 38 . The $\mathrm{Co}-3$ gene ( $\mathrm{Co}-3 / 9$ locus) was first described as the only resistance locus present in the differential cultivar Mexico 222 (6) but the presence of a second unidentified dominant resistance locus was later reported (54). The Co-3/9 locus present in Mexico 222 was directly mapped (LG 4), and its organization as a cluster of at least three different genes conferring specific resistance to races 19,31 , and 38 , respectively, was demonstrated (50). The presence of $C o-3 / 9$ (40), as well as 
that of $\mathrm{Co}-4$ and other undefined complementary genes (4), has been described in PI207262 from the results of different allelism tests. In the differential cultivar $\mathrm{TO}$, the Co-4 locus was first described as a single major gene conferring resistance to anthracnose pathotypes $\Delta$ and $\gamma$-2 (16). The Co-5 locus was first described in the differential cultivar TU (16) and, to date, it was assumed to be the only anthracnose resistance locus present in this cultivar. However, a recent work of Campa et al. (10) demonstrated by direct mapping that TU carries at least three independent loci, one of which, located in LG 7 (corresponding to the $\mathrm{Co}-5$ locus), is formed by a cluster of at least eight different genes conferring specific resistance to races $3,6,7,31,38,39$, 102, and 449, respectively; a second locus confers resistance to races 31 and 102, and a third locus confers specific resistance to race 102 , the location of these two loci remaining unknown. In the differential cultivar AB136, the Co-6 locus (59), the recessive gene $c o-8$ (2), and a second unspecified independent dominant resistance gene (11) have been reported. Using allelism tests, three independent loci ( $\mathrm{Co}-4, \mathrm{Co}-5$, and $\mathrm{Co}-7)$ were reported to be present in the differential cultivar G2333 (61).

Kaboon is among the anthracnose differential cultivars showing the highest resistance spectrum to most of the $C$. lindemuthianum races $(5,33)$. Although there is importance of the anthracnose resistance system present in Kaboon, it has not been fully elucidated and no attempts have been made to map the resistance loci. The main objective of this work was to characterize and map the genes conferring specific resistance against eight anthracnose races in this differential cultivar.

\section{MATERIALS AND METHODS}

Plant material. Molecular marker analyses were carried out using DNA extracted from $99 \mathrm{~F}_{2}$ plants derived from the cross between the anthracnose differential cultivars Kaboon and Michelite. The corresponding $99 \mathrm{~F}_{3}$ families were used to characterize the $\mathrm{F}_{2}$ plants for resistance to eight anthracnose races (races $3,7,19,31,81,453,449$, and 1545). Based on the combined segregations of anthracnose resistance specificities and molecular markers, a specific $\mathrm{F}_{3}$ family $\left(\mathrm{F}_{3}-28\right)$ was chosen in order to perform a genetic analysis of the resistance to races 449,453 , and
1545. The characterization for resistance to anthracnose races 449,453 , and 1545 was carried out in $46 \mathrm{~F}_{4}$ families proceeding from family $\mathrm{F}_{3}-28$. Molecular marker analyses were also carried out using DNA extracted from the corresponding $46 \mathrm{~F}_{3}-28$ plants.

DNA extraction, polymerase chain reaction amplification, and electrophoresis. Genomic DNA was isolated from young leaves using the FastDNA kit (MP Biomedicals, Illkirch, France) following the supplier's instructions. DNA concentrations were quantified photometrically (absorbance measurements at 260 and $280 \mathrm{~nm}$ ) with Biomate $3 \mathrm{UV}$-visible spectrophotometer (Thermo Scientific, MA). DNA markers analyzed in $\mathrm{F}_{2}$ Kaboon $\times$ Michelite are shown in Table 1. Another 55 DNA markers, microsatellite (simple-sequence repeat [SSR]), and sequence-characterized amplified region (SCAR) markers were analyzed in the $\mathrm{F}_{3}-28$ family. Data concerning these markers are available upon request. The polymerase chain reaction (PCR) amplifications of these molecular markers were carried out in a $20-\mu \mathrm{l}$ solution containing $25 \mathrm{ng}$ of DNA, $100 \mathrm{mM}$ Tris- $\mathrm{HCl}, 100 \mathrm{mM} \mathrm{KCl}$ (pH 8.3), $4 \mathrm{mM} \mathrm{MgCl} \mathrm{mg}_{2}$, $0.2 \mathrm{mM}$ each dNTP (Bioline, London), $0.2 \mu \mathrm{M}$ each primer, and $1.25 \mathrm{U}$ of Biotaq DNA polymerase (Bioline). Amplifications were performed in a Veriti thermal cycler (Applied Biosystems, Life Technologies, Foster City, CA) programmed according to the corresponding author. The SCAR PCR products were resolved on $2 \%$ agarose gels. The SSR PCR products were resolved on $8 \%$ polyacrylamide gels, except for marker BM172, in which infrared dye labeled forward primer (IRD-700) and an automated sequencer with fluorometric detection (LiCor 4300 DNA analyzer) was used. Agarose and polyacrylamide gels were stained with SYBR safe (Invitrogen, Life Technologies, CA) and visualized under UV light.

Inoculation procedure and disease scoring. Eight different races of $C$. lindemuthianum were used: races 7, 31, 81, 453, 449, and 1545 from the collection of the Crop and Soil Sciences Department (Michigan State University), and races 3 and 19 from the collection of the SERIDA (Villaviciosa, Asturias, Spain). The virulence and avirulence patterns of the $C$. lindemuthianum races used in this work on the standard set of 12 common bean differential cultivars are shown in Table 2. Isolates of each race were obtained from monosporic cultures maintained in funguscolonized filter paper at $-20^{\circ} \mathrm{C}$ for long-term storage. To obtain

TABLE 1 . Molecular markers analyzed in the Kaboon $\times$ Michelite $\mathrm{F}_{2}$ population ${ }^{\mathrm{a}}$

\begin{tabular}{|c|c|c|c|c|c|c|c|c|}
\hline \multirow[b]{2}{*}{ Marker name } & \multirow[b]{2}{*}{ Type $^{b}$} & \multirow[b]{2}{*}{ LG } & \multirow[b]{2}{*}{ Linked to ${ }^{c}$} & \multirow[b]{2}{*}{ Reference } & \multicolumn{2}{|c|}{ Parental phenotypes ${ }^{\mathrm{d}}$} & \multirow[b]{2}{*}{$\chi^{2}$} & \multirow[b]{2}{*}{ Probability } \\
\hline & & & & & Kaboon & Michelite & & \\
\hline $\mathrm{OF} 10_{530}$ & RAPD & 1 & $\mathrm{Co}-1$ & 51,60 & $\ldots$ & 530 & 0.46 & 0.50 \\
\hline AT003 & SSR & 1 & $\ldots$ & 8 & 125 & 135 & 4.62 & 0.10 \\
\hline BMd45-AIA & SSR & 1 & fin & 9,45 & 250 & 200 & 6.61 & 0.04 \\
\hline BM200 & SSR & 1 & $\ldots$ & 9 & 221 & $\ldots$ & 5.60 & 0.02 \\
\hline BM167 & SSR & 2 & $\ldots$ & 9 & 165 & $\ldots$ & 0.06 & 0.81 \\
\hline BM172 & SSR & 3 & $\ldots$ & 9 & 112 & 77 & 3.69 & 0.16 \\
\hline BMd26 & SSR & 4 & $\ldots$ & 9 & 135 & 140 & 7.36 & 0.03 \\
\hline ATA20 & SSR & 4 & $\ldots$ & 8 & $\ldots$ & 150 & 1.38 & 0.24 \\
\hline BM140 & SSR & 4 & $\ldots$ & 9 & 180 & 160 & 2.89 & 0.24 \\
\hline $\mathrm{OF} 10_{1100}$ & RAPD & 4 & Co- 10 & 3,30 & 1,100 & $\ldots$ & 0.19 & 0.66 \\
\hline SW12 & SCAR & 4 & Co-3/9 & 40,43 & 700 & $\ldots$ & 1.52 & 0.22 \\
\hline SB10 & SCAR & 4 & HBB & 17 & 525 & $\ldots$ & 0.97 & 0.32 \\
\hline PV-ctt001 & SSR & 4 & $\mathrm{Co}-3 / 9$ & 9,51 & 162 & 175 & 0.42 & 0.81 \\
\hline SI19 & SCAR & 4 & $U r-5$ & 37,43 & 460 & $\ldots$ & 0.06 & 0.81 \\
\hline BM210 & SSR & 7 & Co-5 & 9,10 & $\ldots$ & 170 & 2.64 & 0.10 \\
\hline Phs & SCAR & 7 & $\mathrm{Co}-5$ & 10,29 & 300 & $\ldots$ & 0.06 & 0.81 \\
\hline SC08 & SCAR & 8 & $\mathrm{Co}-4$ & 9,48 & 910 & $\ldots$ & 0.24 & 0.62 \\
\hline PV-ag001 & SSR & 11 & $\mathrm{Co}-2$ & 9,47 & 160 & 150 & 3.77 & 0.15 \\
\hline
\end{tabular}

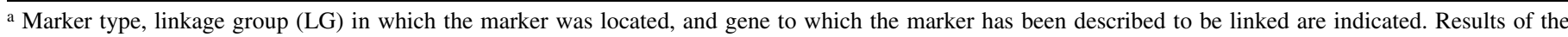
comparison between the segregations of the molecular markers and the corresponding expected monogenic segregations are shown (the detailed results can be obtained upon request).

${ }^{\mathrm{b}} \mathrm{RAPD}=$ random amplified polymorphic DNA, SSR = simple-sequence repeat, and SCAR = sequence-characterized amplified region.

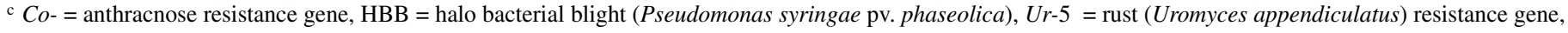
and fin $=$ determinate growth habit gene.

${ }^{\mathrm{d}}$ For DNA molecular markers, the parental phenotype refers to the size of the amplified products, expressed in base pairs. 
abundant sporulation, all races were grown at 19 to $21^{\circ} \mathrm{C}$ in darkness for $\approx 10$ days in potato dextrose agar (Difco, Becton Dickinson and Company, Sparks, MD). Spore suspensions were prepared by flooding the plates with $5 \mathrm{ml}$ of $0.01 \%$ Tween 20 (Sigma-Aldrich, St. Louis) in sterile distilled water and scraping the surface of the culture with a spatula. Differential cultivars and $\mathrm{F}_{3}$ and $\mathrm{F}_{4}$ families were inoculated with a spore suspension of the pathogen at $1.2 \times 10^{6} \mathrm{spores} / \mathrm{ml}$. Inoculations were carried out on 8 - to 10-day-old seedlings in a climate chamber. The seedlings were sprayed with the aqueous conidial suspension and maintained at 20 to $22^{\circ} \mathrm{C}, 95$ to $100 \%$ humidity, and a 12-h photoperiod. The responses of the plants were evaluated after 7 to 9 days using a 1-to-9 scale (56). Seedlings with no visible symptoms (severity value 1) or showing limited necrotic lesions (severity values 2 to 3 ) were considered resistant. Seedlings with large sporulating lesions (severity values 4 to 8 ) or dead (severity value 9) were considered susceptible. Resistance to each race was evaluated in separate experiments. Each experiment consisted on one evaluation including the parental differential cultivars Kaboon and Michelite, 10 to 20 plants per $\mathrm{F}_{3}$ family or $\mathrm{F}_{4}$ family, and the remaining 10 common bean anthracnose differential cultivars used to confirm the identity of the $C$. lindemuthianum isolates.

Statistical and linkage analyses. To test goodness-of-fit of observed/expected ratios in the $\mathrm{F}_{2}$ population Kaboon $\times$ Michelite and in the corresponding $\mathrm{F}_{3}$ progenies, $\chi^{2}$ was used. Linkage analyses between the markers and the resistance genes were performed using MAPMAKER (Macintosh version 2.0) (32). LGs were established with a log of the likelihood ratio (LOD) threshold of 3.0 and a recombination fraction of 0.25 . Marker order was estimated based on multipoint compare, order, and ripple analyses. Distances between ordered loci (in centimorgans) were calculated using the Kosambi mapping function.

\section{RESULTS}

Segregations of anthracnose resistance specificities. Parental Kaboon was resistant to races 3, 7, 19, 31, 81, 449, 453, and 1545 of $C$. lindemuthianum, whereas parental Michelite was susceptible to all these races. For each anthracnose race, the $F_{3}$ Kaboon $\times$ Michelite families were classified as $\mathrm{R}$, having all individuals resistant (all individuals resistant to race $\mathrm{X}=\mathrm{R}^{\mathrm{X}}$ ); $\mathrm{R} / \mathrm{S}$, having individuals resistant and susceptible (individuals resistant and susceptible to race $\mathrm{X}=\mathrm{R} / \mathrm{S}^{\mathrm{X}}$ ); and $\mathrm{S}$, having all individuals susceptible (all individuals susceptible to race $\mathrm{X}=$ $S^{X}$ ). Segregations of $F_{3}$ families for resistance to races, 3, 7, 19, $31,81,449,453$, and 1545 are shown in Table 3. Segregations for resistance to races $3,7,19$, and 81 showed a good fit to the expected ratio for a single dominant gene (1:2:1, R:R/S:S). Segregations for resistance to races 449,453 , and 1545 showed no significant differences when compared with the expected ratio for two independent dominant genes (7:8:1, R:R/S:S). Segregation for resistance to race 31 showed a good fit to the expected ratio for resistance being determined by the simultaneous presence of two dominant independently located genes (two complementary genes $=1: 8: 7, \mathrm{R}: \mathrm{R} / \mathrm{S}: \mathrm{S}$ ). In Table 3 , the observed segregation for resistance to race 1545 is also compared with the expected ratio for three independent dominant genes $(37: 26: 1$, $\mathrm{R}: \mathrm{R} / \mathrm{S}: \mathrm{S})$. In this case, the highly significant difference found is mainly due to the very low expected number (1.3) of $F_{3}$ families having all individuals susceptible ( $\mathrm{S})$, a good fit being attained in the other two classes (R and R/S). Notwithstanding, there are some reasons that support the possibility that resistance to race 1545 is determined by three independent dominant genes (see below).

Segregations of molecular markers. The results of the comparison between the segregations of the molecular markers and the corresponding expected monogenic segregations are shown in

TABLE 2. Virulence and avirulence patterns of the Colletotrichum lindemuthianum races used in this work $(\mathrm{S}=$ susceptible and $\mathrm{R}=$ resistant)

\begin{tabular}{|c|c|c|c|c|c|c|c|c|c|}
\hline \multirow[b]{2}{*}{ Differential cultivar } & \multirow[b]{2}{*}{ Binary value } & \multicolumn{8}{|c|}{ Race } \\
\hline & & 3 & 7 & 19 & 31 & 81 & 449 & 453 & 1545 \\
\hline Michelite & 1 & $\mathrm{~S}$ & $\mathrm{~S}$ & $\mathrm{~S}$ & $\mathrm{~S}$ & $\mathrm{~S}$ & $\mathrm{~S}$ & $\mathrm{~S}$ & $\mathrm{~S}$ \\
\hline MDRK & 2 & $\mathrm{~S}$ & $S$ & $\mathrm{~S}$ & $\mathrm{~S}$ & $\mathrm{R}$ & $\mathrm{R}$ & $\mathrm{R}$ & $\mathrm{R}$ \\
\hline Perry Marrow & 4 & $\mathrm{R}$ & $S$ & $\mathrm{R}$ & $\mathrm{S}$ & $\mathrm{R}$ & $\mathrm{R}$ & $\mathrm{S}$ & $\mathrm{R}$ \\
\hline Cornell 49242 & 8 & $\mathrm{R}$ & $\mathrm{R}$ & $\mathrm{R}$ & $\mathrm{S}$ & $\mathrm{R}$ & $\mathrm{R}$ & $\mathrm{R}$ & $\mathrm{S}$ \\
\hline Widusa & 16 & $\mathrm{R}$ & $\mathrm{R}$ & $\mathrm{S}$ & $\mathrm{S}$ & $\mathrm{S}$ & $\mathrm{R}$ & $\mathrm{R}$ & $\mathrm{R}$ \\
\hline Kaboon & 32 & $\mathrm{R}$ & $\mathrm{R}$ & $\mathrm{R}$ & $\mathrm{R}$ & $\mathrm{R}$ & $\mathrm{R}$ & $\mathrm{R}$ & $\mathrm{R}$ \\
\hline Mex222 & 64 & $\mathrm{R}$ & $\mathrm{R}$ & $\mathrm{R}$ & $\mathrm{R}$ & $\mathrm{S}$ & $\mathrm{S}$ & $\mathrm{S}$ & $\mathrm{R}$ \\
\hline PI207262 & 128 & $\mathrm{R}$ & $\mathrm{R}$ & $\mathrm{R}$ & $\mathrm{R}$ & $\mathrm{R}$ & $\mathrm{S}$ & $\mathrm{S}$ & $\mathrm{R}$ \\
\hline TO & 256 & $\mathrm{R}$ & $\mathrm{R}$ & $\mathrm{R}$ & $\mathrm{R}$ & $\mathrm{R}$ & $\mathrm{S}$ & $\mathrm{S}$ & $\mathrm{R}$ \\
\hline TU & 512 & $\mathrm{R}$ & $\mathrm{R}$ & $\mathrm{R}$ & $\mathrm{R}$ & $\mathrm{R}$ & $\mathrm{R}$ & $\mathrm{R}$ & $\mathrm{S}$ \\
\hline AB136 & 1,024 & $\mathrm{R}$ & $\mathrm{R}$ & $\mathrm{R}$ & $\mathrm{R}$ & $\mathrm{R}$ & $\mathrm{R}$ & $\mathrm{R}$ & S \\
\hline G2333 & 2,048 & $\mathrm{R}$ & $\mathrm{R}$ & $\mathrm{R}$ & $\mathrm{R}$ & $\mathrm{R}$ & $\mathrm{R}$ & $\mathrm{R}$ & $\mathrm{R}$ \\
\hline
\end{tabular}

TABLE 3. Segregation for resistance to races 3, 7, 19, 31, 81, 449, 453, and 1545 of Colletotrichum lindemuthianum in the $\mathrm{F}_{3}$ Kaboon $\times$ Michelite families

\begin{tabular}{|c|c|c|c|c|c|c|c|c|}
\hline \multirow[b]{2}{*}{ Race $^{\mathrm{a}}$} & \multicolumn{2}{|c|}{ Parental phenotypes ${ }^{b}$} & \multicolumn{4}{|c|}{$\mathrm{F}_{3}$ Kaboon $\times$ Michelite families ${ }^{\mathrm{c}}$} & \multirow[b]{2}{*}{$\chi^{2}$} & \multirow[b]{2}{*}{$P$} \\
\hline & Kaboon & Michelite & $\mathrm{R}$ & $\mathrm{R} / \mathrm{S}$ & $\mathrm{S}$ & Each segregation tested against & & \\
\hline 3 & $\mathrm{R}$ & $\mathrm{S}$ & 17 & 52 & 22 & One dominant gene & 2.41 & 0.30 \\
\hline 7 & $\mathrm{R}$ & $\mathrm{S}$ & 15 & 53 & 22 & One dominant gene & 3.93 & 0.14 \\
\hline 19 & $\mathrm{R}$ & $\mathrm{S}$ & 17 & 56 & 23 & One dominant gene & 3.42 & 0.18 \\
\hline 31 & $\mathrm{R}$ & $\mathrm{S}$ & 4 & 28 & 35 & Two complementary genes & 2.01 & 0.37 \\
\hline 81 & $\mathrm{R}$ & $\mathrm{S}$ & 16 & 29 & 24 & One dominant gene & 3.61 & 0.16 \\
\hline 449 & $\mathrm{R}$ & $\mathrm{S}$ & 41 & 41 & 10 & Two independent dominant genes & 3.70 & 0.16 \\
\hline 453 & $\mathrm{R}$ & $\mathrm{S}$ & 38 & 41 & 10 & Two independent dominant genes & 3.84 & 0.15 \\
\hline 1545 & $\mathrm{R}$ & $\mathrm{S}$ & 45 & 32 & 7 & Two independent dominant genes & 4.82 & 0.09 \\
\hline 1545 & $\mathrm{R}$ & $\mathrm{S}$ & 45 & 32 & 7 & Three independent dominant genes & 25.04 & 0.00 \\
\hline
\end{tabular}

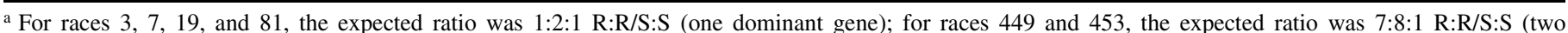
independent dominant genes); and for race 31 the expected ratio was 1:8:7 R:R/S:S (two independent complementary dominant genes). Segregation of resistance to race 1545 is compared with expected ratios 7:8:1 R:R/S:S (two independent dominant genes) and 37:26:1 R:R/S:S (three independent dominant genes).

${ }^{\mathrm{b}} \mathrm{R}=$ resistant and $\mathrm{S}=$ susceptible.

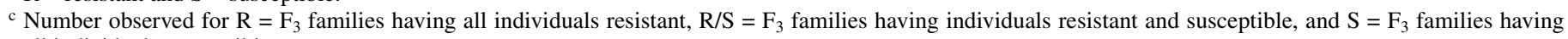
all individuals susceptible. 
Table 1 (the detailed results can be obtained upon request). A good fit to the expected ratio for a single locus was obtained in all cases, except for the microsatellites BMd45-AIA, BM200, and BMd26, in which a significant excess of the alleles corresponding to parental Michelite was observed.

Linkage analyses. Resistance to races 3, 7, 19, and 81 (showing monogenic segregation). Resistance to race 81 segregated independently from resistance to races 3, 7, and 19 (the values of the contingency $\chi^{2}$ tests are 6.07, 4.74, and 5.97, respectively, $P>$ 0.05 in the three cases). The results of the linkage analysis between the locus conferring specific resistance to race 81 and each one of the DNA markers indicated in Table 1 are shown in Table 4. This resistance locus is significantly linked (LOD $>3$ ) to the molecular markers previously located in LG $1, \mathrm{OF} 10_{530}$ (linked to $C o-1)$, and AT003 $(8,51,60)$. From these results, it can be concluded that resistance to race 81 present in Kaboon is conferred by a gene corresponding to the $\mathrm{Co}-1$ locus.

Resistance to the three races 3, 7, and 19 was evaluated in $88 \mathrm{~F}_{3}$ families (the remaining $11 \mathrm{~F}_{3}$ families could only be evaluated for one or two of these races). Co-segregation for resistance to the three races was observed in 85 of these $F_{3}$ families $\left(14 \mathrm{~F}_{3}\right.$ families $=R^{3} R^{7} R^{19}, 49 F_{3}$ families $=R / S^{3} R / S^{7} R / S^{19}$, and $22 F_{3}$ families $=S^{3} S^{7} S^{19}$ ) and only in three cases was evidence of recombination found (two $F_{3}$ families $=R^{3} R / S^{7} R^{19}$ and one $F_{3}$ family $=R^{3} R^{7} R / S^{19}$ ). The recombinant nature of these $F_{3}$ families was confirmed by increasing the number of $F_{3}$ individuals evaluated for resistance. These results indicate that three different race-specific, closely linked genes determine the resistance to races 3,7 , and 19 , respectively. The results of the linkage analysis between the locus conferring specific resistance to race 3 and each one of the DNA markers indicated in Table 1 are shown in Table 5 (values almost identical to the ones shown in Table 5 were obtained for loci conferring specific resistance to races 7 and 19). These resistance loci are significantly linked (LOD $>3$ ) to the molecular markers located in LG 4, OF10 1100 , SW12, SB10, Pvctt001, and SI19, most of them previously linked to Co-3/9 $(17,40,43,50,51,62)$. This indicates that the three clustered genes conferring specific resistance to races 3,7 , and 19 , respectively, correspond to the $\mathrm{Co}-3 / 9$ locus.

The genetic map of LG 1 and LG 4 obtained from the segregation data is shown in Figure 1.
Resistance to races 449, 453, and 1545. The results shown in Table 3 indicate that resistance to race 449 and resistance to race 453 are conferred by two independent dominant genes each. Resistance to these two races was evaluated in $88 \mathrm{~F}_{3}$ families (the remaining $11 \mathrm{~F}_{3}$ families could not be evaluated for both races). Co-segregation for resistance to races 449 and 453 was observed in 83 of these $F_{3}$ families $\left(35 F_{3}\right.$ families $=R^{449} R^{453}, 38 F_{3}$ families $=R / S^{449} R / S^{453}$, and $10 F_{3}$ families $=S^{449} S^{453}$ ) and only in five cases was evidence of recombination found (3 $\mathrm{F}_{3}$ families $=R^{449} R / S^{453}$ and $2 F_{3}$ families $=R / S^{449} R^{453}$ ). The recombinant nature of these $\mathrm{F}_{3}$ families was confirmed by increasing the number of $\mathrm{F}_{3}$ individuals evaluated for resistance. This result agrees with the assumption that resistance to races 449 and 453 in Kaboon is determined by two independent clusters, each one containing two closely linked race-specific genes, one of these genes conferring resistance to race 449 and the other conferring resistance to race 453 .

Contingency $\chi^{2}$ tests corresponding to the joint segregation of resistance to races 449 and 453, respectively, with each one of the resistances to monogenic races $3,7,19$, and 81 and with the molecular markers appearing in Table 1 are shown in Table 6. For both races, the $\chi^{2}$ values deviate significantly from the expectation of random segregation when monogenic races 3,7 , and 19 and markers linked to the Co-3/9 locus $\left(\mathrm{OF} 10_{1100}\right.$, SW12, SB10, PV-ctt001, and SI19) are considered. These results indicate that one of the two independent clusters including specific resistance genes against races 449 and 453 corresponds to the $\mathrm{Co}$-3/9 locus.

Contingency $\chi^{2}$ tests corresponding to the joint segregation of resistance to race 1545 with each one of the resistances to monogenic races, $3,7,19$, and 81 and with the markers appearing in Table 1 are shown in Table 6 . The $\chi^{2}$ values deviate significantly from the expectation of random segregation when monogenic races 3, 7, 19, and 81 and markers linked to the Co-1 $\left(\mathrm{OF} 10_{530}\right)$ and the $\mathrm{Co}-3 / 9$ loci $\left(\mathrm{OF} 10_{1100}, \mathrm{SW} 12, \mathrm{SB} 10, \mathrm{PV}\right.$-ctt001, and SI19) are considered. These results indicate that one of the genes conferring resistance to race 1545 corresponds to locus $\mathrm{Co}$ 1 , and that a second gene corresponds to locus $\mathrm{Co}-3 / 9$.

A specific $\mathrm{F}_{3}$ family $\left(\mathrm{F}_{3}-28\right)$ was analyzed in more detail. The $\mathrm{F}_{3}-28$ family had the resistance spectrum $\mathrm{S}^{3} \mathrm{~S}^{7} \mathrm{~S}^{19} \mathrm{~S}^{81} \mathrm{R} / \mathrm{S}^{449}$ $\mathrm{R} / \mathrm{S}^{453} \mathrm{R} / \mathrm{S}^{1545}$ and was homozygous for the alleles corresponding to parental Michelite for the markers closely linked to cluster

TABLE 4. Linkage analysis between the gene conferring resistance to race 81 and each one of the DNA markers indicated in Table $1^{\text {a }}$

\begin{tabular}{|c|c|c|c|c|c|c|c|c|c|c|c|c|c|c|c|c|c|c|}
\hline \multirow{2}{*}{\multicolumn{2}{|c|}{ Markers }} & \multicolumn{15}{|c|}{$\mathrm{F}_{3}$ Kaboon $\times$ Michelite families } & \multirow[b]{3}{*}{$\mathrm{RF}$} & \multirow[b]{3}{*}{ LOD } \\
\hline & & \multicolumn{5}{|c|}{$\mathrm{R}^{81}$} & \multicolumn{5}{|c|}{$\mathrm{R} / \mathrm{S}^{81}$} & \multicolumn{5}{|c|}{$\mathrm{S}^{81}$} & & \\
\hline Name & $\mathrm{LG}^{\mathrm{b}}$ & $\mathrm{K} / \mathrm{K}$ & $\mathrm{K} /-$ & $\mathrm{K} / \mathrm{M}$ & $\mathrm{M} /-$ & $\mathrm{M} / \mathrm{M}$ & $\mathrm{K} / \mathrm{K}$ & $\mathrm{K} /-$ & $\mathrm{K} / \mathrm{M}$ & $\mathrm{M} /-$ & $\mathrm{M} / \mathrm{M}$ & $\mathrm{K} / \mathrm{K}$ & $\mathrm{K} /-$ & $\mathrm{K} / \mathrm{M}$ & $\mathrm{M} /-$ & $\mathrm{M} / \mathrm{M}$ & & \\
\hline $\mathrm{OF} 10_{530}$ & 1 & 10 & $\ldots$ & $\ldots$ & 3 & $\ldots$ & 3 & $\ldots$ & $\ldots$ & 23 & $\ldots$ & 0 & $\ldots$ & $\ldots$ & 23 & $\ldots$ & 0.11 & 6.71 \\
\hline AT003 & 1 & 7 & $\ldots$ & 5 & $\ldots$ & 2 & 0 & $\ldots$ & 20 & $\ldots$ & 4 & 2 & $\ldots$ & 7 & $\ldots$ & 13 & 0.23 & 4.63 \\
\hline BMd45-AIA & 1 & 4 & $\ldots$ & 7 & $\ldots$ & 3 & 1 & $\ldots$ & 18 & $\ldots$ & 7 & 1 & $\ldots$ & 9 & $\ldots$ & 13 & 0.30 & 2.54 \\
\hline BM200 & 1 & $\ldots$ & 10 & $\ldots$ & $\ldots$ & 4 & $\ldots$ & 18 & $\ldots$ & $\ldots$ & 7 & $\ldots$ & 11 & $\ldots$ & $\ldots$ & 12 & 0.37 & 0.89 \\
\hline BM167 & 2 & $\ldots$ & 10 & $\ldots$ & $\ldots$ & 4 & $\ldots$ & 18 & $\ldots$ & $\ldots$ & 8 & $\ldots$ & 18 & $\ldots$ & $\ldots$ & 5 & 0.50 & 0.00 \\
\hline BM172 & 3 & 1 & $\ldots$ & 9 & $\ldots$ & 4 & 11 & $\ldots$ & 8 & $\ldots$ & 7 & 6 & $\ldots$ & 8 & $\ldots$ & 8 & 0.50 & 0.00 \\
\hline BMd26 & 4 & 3 & $\ldots$ & 4 & $\ldots$ & 7 & 3 & $\ldots$ & 9 & $\ldots$ & 14 & 8 & $\ldots$ & 11 & $\ldots$ & 4 & 0.50 & 0.00 \\
\hline ATA20 & 4 & 2 & $\ldots$ & $\ldots$ & 12 & $\ldots$ & 4 & $\ldots$ & $\ldots$ & 22 & $\ldots$ & 7 & $\ldots$ & $\ldots$ & 16 & $\ldots$ & 0.50 & 0.00 \\
\hline BM140 & 4 & 2 & $\ldots$ & 9 & $\ldots$ & 3 & 4 & $\ldots$ & 13 & $\ldots$ & 9 & 5 & $\ldots$ & 10 & $\ldots$ & 7 & 0.48 & 0.01 \\
\hline $\mathrm{OF} 10_{1100}$ & 4 & $\ldots$ & 11 & $\ldots$ & $\ldots$ & 2 & $\ldots$ & 20 & $\ldots$ & $\ldots$ & 6 & $\ldots$ & 16 & $\ldots$ & $\ldots$ & 7 & 0.42 & 0.20 \\
\hline SW12 & 4 & $\ldots$ & 12 & $\ldots$ & $\ldots$ & 2 & $\ldots$ & 18 & $\ldots$ & $\ldots$ & 8 & $\ldots$ & 13 & $\ldots$ & $\ldots$ & 10 & 0.36 & 0.92 \\
\hline SB10 & 4 & $\ldots$ & 12 & $\ldots$ & $\ldots$ & 2 & $\ldots$ & 18 & $\ldots$ & $\ldots$ & 8 & $\ldots$ & 14 & $\ldots$ & $\ldots$ & 9 & 0.38 & 0.63 \\
\hline PV-ctt001 & 4 & 6 & $\ldots$ & 6 & $\ldots$ & 2 & 4 & $\ldots$ & 17 & $\ldots$ & 5 & 6 & $\ldots$ & 11 & $\ldots$ & 6 & 0.43 & 0.24 \\
\hline SI19 & 4 & $\ldots$ & 13 & $\ldots$ & $\ldots$ & 1 & $\ldots$ & 20 & $\ldots$ & $\ldots$ & 6 & $\ldots$ & 17 & $\ldots$ & $\ldots$ & 6 & 0.41 & 0.25 \\
\hline BM210 & 7 & 3 & $\ldots$ & $\ldots$ & 8 & $\ldots$ & 7 & $\ldots$ & $\ldots$ & 16 & $\ldots$ & 7 & $\ldots$ & $\ldots$ & 13 & $\ldots$ & 0.50 & 0.00 \\
\hline Phs & 7 & $\ldots$ & 9 & $\ldots$ & $\ldots$ & 5 & $\ldots$ & 21 & $\ldots$ & $\ldots$ & 5 & $\ldots$ & 15 & $\ldots$ & $\ldots$ & 8 & 0.47 & 0.02 \\
\hline SC08 & 8 & $\ldots$ & 9 & $\ldots$ & $\ldots$ & 5 & $\ldots$ & 22 & $\ldots$ & $\ldots$ & 4 & $\ldots$ & 17 & $\ldots$ & $\ldots$ & 6 & 0.50 & 0.00 \\
\hline PV-ag001 & 11 & 5 & $\ldots$ & 5 & $\ldots$ & 4 & 6 & $\ldots$ & 12 & $\ldots$ & 8 & 3 & $\ldots$ & 9 & $\ldots$ & 10 & 0.40 & 0.73 \\
\hline
\end{tabular}

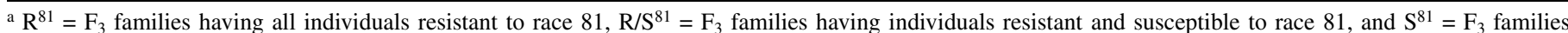

having all individuals susceptible to race $81 . \mathrm{K} / \mathrm{K}=$ homozygous for the Kaboon alleles of the corresponding marker, $\mathrm{K} /-=$ homozygous for the Kaboon alleles or heterozygous, $\mathrm{K} / \mathrm{M}=$ heterozygous, $\mathrm{M} /-=$ homozygous for the Michelite alleles or heterozygous, and $\mathrm{M} / \mathrm{M}=\mathrm{homozygous}$ for the Michelite alleles. Linkage values are expressed as recombination fraction (RF) and log of the likelihood ration (LOD).

b Linkage group in which the marker is located. 
Co-1 (OF10 ${ }_{530}$ and AT003) and for the markers flanking the Co$3 / 9$ cluster $\left(\mathrm{OF} 10_{1100}, \mathrm{SW} 12, \mathrm{SB} 10, \mathrm{PV}-\mathrm{ctt} 001\right.$, and SI19). Then, most probably, the Kaboon haplotype of cluster $\mathrm{Co}-1$, bearing the genes conferring resistance to races 81 and 1545, and the Kaboon haplotype of cluster $\mathrm{Co}-3 / 9$, bearing the genes conferring resistance to races $3,7,19,449,453$, and 1545 , were lacking in the $\mathrm{F}_{3}-28$ family, the segregation for resistance to races 449,453 , and 1545 shown by this family being due to heterozygosity in the second cluster carrying resistance to races 449 and 453, indicated before, and to a third gene conferring resistance to race 1545 . In total, 46 individuals of the $F_{3}-28$ family were selfed and their progenies $\left(\mathrm{F}_{4}-28\right.$ families) were analyzed for resistance to races 449, 453, and 1545. Monogenic segregations were observed for the three resistance specificities (race 449: $10 \mathrm{R}, 28 \mathrm{R} / \mathrm{S}, 8 \mathrm{~S}, \chi^{2}=$ $2.35, P=0.31$; race 453: $6 \mathrm{R}, 27 \mathrm{R} / \mathrm{S}, 6 \mathrm{~S}, \chi^{2}=5.77, P=0.06$; and race 1545: $6 \mathrm{R}, 22 \mathrm{R} / \mathrm{S}, 8 \mathrm{~S}, \chi^{2}=2.00, P=0.37$ ), and the analysis of the recombination fractions (RFs) between the corresponding three resistance loci indicated that they were significantly linked $\left(\mathrm{RF}_{449-453}=0.10, \mathrm{LOD}=6.73 ; \mathrm{RF}_{449-1545}=0.17\right.$, $\left.\mathrm{LOD}=3.46 ; \mathrm{RF}_{453-1545}=0.20, \mathrm{LOD}=2.05\right)$. These results support the idea that, in addition to $\mathrm{Co}-1$ and $\mathrm{Co}-3 / 9$, Kaboon has a third cluster bearing genes for specific resistance to races 449 , 453 , and 1545 , with the gene conferring resistance to race 449 occupying the central position.

In order to map this cluster, its linkage relationship to 55 molecular markers (different from those indicated in Table 1), previously mapped in all LGs, was tested in the $\mathrm{F}_{3}-28$ family. Parental Kaboon and Michelite were polymorphic for 33 of these markers, 19 of them being monomorphic in the $\mathrm{F}_{3}-28$ family and the remaining 14 being not linked to the resistance cluster (more detailed data concerning these analyses are available upon request).

Resistance to race 31. The results shown in Table 3 indicate that two independent complementary genes are necessary for resistance to race 31 in Kaboon. Contingency $\chi^{2}$ tests corresponding to the joint segregation of resistance to race 31 with each one of the resistances to monogenic races, 3, 7, 19, and 81 and with the markers appearing in Table 1 are shown in Table 6. The $\chi^{2}$ values deviate significantly from the expectation of random segregation when monogenic races $3,7,19$, and 81 , and markers linked to the Co- 1 (OF10 $0_{530}$, AT003, and BMd45) and the
Co-3/9 loci (BM140, OF10 $1100, \mathrm{SW} 12, \mathrm{SB} 10, \mathrm{PV}-\mathrm{ctt} 001$, and SI19) are considered. From these results, it can be inferred that one of the complementary genes conferring resistance to race 31 corresponds to locus $\mathrm{Co}-\mathrm{l}$ and the other corresponds to locus $\mathrm{Co}$ $3 / 9$.

The resistance spectrum of 13 of the $99 \mathrm{~F}_{3}$ families analyzed showed evidence of intracluster recombination between either the genes conferring resistance to races 31 and 81 in cluster $C o-l$ (for instance, $S^{81} R^{3} R^{7} R^{19} R / S^{31}$ ) or between the gene conferring resistance to race 31 and the genes conferring resistance to races 3,7 , and 19, in cluster $C o-3 / 9$ (for instance, $\mathrm{R}^{81} \mathrm{~S}^{3} \mathrm{~S}^{7} \mathrm{~S}^{19} \mathrm{R} / \mathrm{S}^{31}$ ). These results indicate that the complementary genes that determine resistance to race 31 are different from the genes that determine resistance to races $81,3,7$, and 19 .

In order to confirm the complementary mode of action of the two loci conferring resistance to race 31 , the $\mathrm{F}_{3}$ families $\mathrm{F}_{3}-64$ and $\mathrm{F}_{3}-105$ were used. The $\mathrm{F}_{3}$ family $\mathrm{F}_{3}-64$ had the resistance spectrum $S^{31} R^{81} S^{3} S^{7} S^{19}$ and was homozygous for the alleles
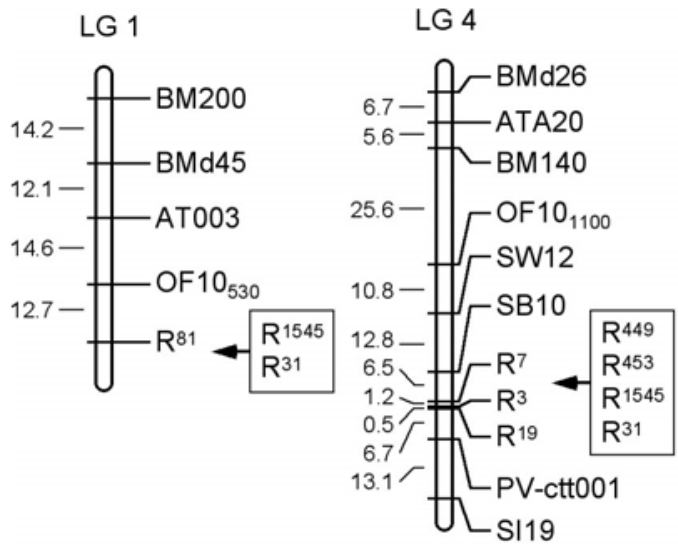

Fig. 1. Linkage map of the genes conferring specific resistance to anthracnose races $3\left(\mathrm{R}^{3}\right), 7\left(\mathrm{R}^{7}\right), 19\left(\mathrm{R}^{19}\right), 31\left(\mathrm{R}^{31}\right), 81\left(\mathrm{R}^{81}\right), 449\left(\mathrm{R}^{449}\right), 453\left(\mathrm{R}^{453}\right)$, and $1545\left(\mathrm{R}^{1545}\right)$ in linkage groups 1 (corresponding to cluster Co-1) and 4 (corresponding to cluster $\mathrm{Co}-3 / 9$ ). Relative positions of the genes $\mathrm{R}^{31}$ and $\mathrm{R}^{1545}$ within the Co- 1 cluster, as well as those of the genes $\mathrm{R}^{31}, \mathrm{R}^{449}, \mathrm{R}^{453}$, and $\mathrm{R}^{1545}$ within the Co-3/9 cluster, are undetermined. Map distances, on the left, are expressed in centimorgans, estimated using the Kosambi mapping function.

TABLE 5. Linkage analysis between the gene conferring resistance to race 3 and each one of the DNA markers indicated in Table $1^{\text {a }}$

\begin{tabular}{|c|c|c|c|c|c|c|c|c|c|c|c|c|c|c|c|c|c|c|}
\hline \multirow{2}{*}{\multicolumn{2}{|c|}{ Markers }} & \multicolumn{15}{|c|}{$\mathrm{F}_{3}$ Kaboon $\times$ Michelite families } & \multirow[b]{3}{*}{$\mathrm{RF}$} & \multirow[b]{3}{*}{ LOD } \\
\hline & & \multicolumn{5}{|c|}{$\mathrm{R}^{3}$} & \multicolumn{5}{|c|}{$\mathrm{R} / \mathrm{S}^{3}$} & \multicolumn{5}{|c|}{$\mathrm{S}^{3}$} & & \\
\hline Name & $\mathrm{LG}^{\mathrm{b}}$ & $\mathrm{K} / \mathrm{K}$ & $\mathrm{K} /-$ & $\mathrm{K} / \mathrm{M}$ & $\mathrm{M} /-$ & $\mathrm{M} / \mathrm{M}$ & $\mathrm{K} / \mathrm{K}$ & $\mathrm{K} /-$ & $\mathrm{K} / \mathrm{M}$ & $\mathrm{M} /-$ & $\mathrm{M} / \mathrm{M}$ & $\mathrm{K} / \mathrm{K}$ & $\mathrm{K} /-$ & $\mathrm{K} / \mathrm{M}$ & $\mathrm{M} /-$ & $\mathrm{M} / \mathrm{M}$ & & \\
\hline $\mathrm{OF} 10_{530}$ & 1 & 4 & $\ldots$ & $\ldots$ & 12 & $\ldots$ & 12 & $\ldots$ & $\ldots$ & 38 & $\ldots$ & 3 & $\ldots$ & $\ldots$ & 17 & $\ldots$ & 0.43 & 0.13 \\
\hline AT003 & 1 & 2 & $\ldots$ & 5 & $\ldots$ & 8 & 9 & $\ldots$ & 29 & $\ldots$ & 12 & 3 & $\ldots$ & 9 & $\ldots$ & 7 & 0.50 & 0.00 \\
\hline BMd45-AIA & 1 & 3 & $\ldots$ & 4 & $\ldots$ & 9 & 7 & $\ldots$ & 30 & $\ldots$ & 14 & 3 & $\ldots$ & 11 & $\ldots$ & 6 & 0.50 & 0.00 \\
\hline BM200 & 1 & $\ldots$ & 7 & $\ldots$ & $\ldots$ & 9 & $\ldots$ & 34 & $\ldots$ & $\ldots$ & 16 & $\ldots$ & 14 & $\ldots$ & $\ldots$ & 5 & 0.50 & 0.00 \\
\hline BM167 & 2 & $\ldots$ & 12 & $\ldots$ & $\ldots$ & 4 & $\ldots$ & 39 & $\ldots$ & $\ldots$ & 12 & $\ldots$ & 13 & $\ldots$ & $\ldots$ & 7 & 0.44 & 0.12 \\
\hline BM172 & 3 & 3 & $\ldots$ & 8 & $\ldots$ & 4 & 19 & $\ldots$ & 20 & $\ldots$ & 12 & 6 & $\ldots$ & 7 & $\ldots$ & 7 & 0.50 & 0.00 \\
\hline $\mathrm{BMd} 26$ & 4 & 4 & $\ldots$ & 8 & $\ldots$ & 4 & 13 & $\ldots$ & 19 & $\ldots$ & 19 & 2 & $\ldots$ & 8 & $\ldots$ & 10 & 0.42 & 0.56 \\
\hline ATA20 & 4 & 5 & $\ldots$ & $\ldots$ & 11 & $\ldots$ & 11 & $\ldots$ & $\ldots$ & 39 & $\ldots$ & 1 & $\ldots$ & $\ldots$ & 19 & $\ldots$ & 0.34 & 0.92 \\
\hline BM140 & 4 & 5 & $\ldots$ & 7 & $\ldots$ & 4 & 11 & $\ldots$ & 27 & $\ldots$ & 12 & 1 & $\ldots$ & 7 & $\ldots$ & 12 & 0.34 & 1.83 \\
\hline $\mathrm{OF} 10_{1100}$ & 4 & $\ldots$ & 16 & $\ldots$ & $\ldots$ & 0 & $\ldots$ & 47 & $\ldots$ & $\ldots$ & 3 & $\ldots$ & 3 & $\ldots$ & $\ldots$ & 17 & 0.07 & 11.64 \\
\hline SW12 & 4 & $\ldots$ & 14 & $\ldots$ & $\ldots$ & 2 & $\ldots$ & 46 & $\ldots$ & $\ldots$ & 5 & $\ldots$ & 1 & $\ldots$ & $\ldots$ & 19 & 0.11 & 9.66 \\
\hline SB10 & 4 & $\ldots$ & 16 & $\ldots$ & $\ldots$ & 0 & $\ldots$ & 45 & $\ldots$ & $\ldots$ & 6 & $\ldots$ & 0 & $\ldots$ & $\ldots$ & 20 & 0.06 & 13.55 \\
\hline PV-ctt001 & 4 & 15 & $\ldots$ & 1 & $\ldots$ & 0 & 3 & $\ldots$ & 44 & $\ldots$ & 2 & 2 & $\ldots$ & 0 & $\ldots$ & 18 & 0.06 & 21.49 \\
\hline SI19 & 4 & $\ldots$ & 16 & $\ldots$ & $\ldots$ & 0 & $\ldots$ & 46 & $\ldots$ & $\ldots$ & 5 & $\ldots$ & 4 & $\ldots$ & $\ldots$ & 16 & 0.10 & 9.36 \\
\hline BM210 & 7 & 0 & $\ldots$ & $\ldots$ & 13 & $\ldots$ & 21 & $\ldots$ & $\ldots$ & 27 & $\ldots$ & 5 & $\ldots$ & $\ldots$ & 13 & $\ldots$ & 0.50 & 0.00 \\
\hline Phs & 7 & $\ldots$ & 11 & $\ldots$ & $\ldots$ & 5 & $\ldots$ & 44 & $\ldots$ & $\ldots$ & 7 & $\ldots$ & 11 & $\ldots$ & $\ldots$ & 9 & 0.38 & 0.36 \\
\hline SC08 & 8 & $\ldots$ & 8 & $\ldots$ & $\ldots$ & 8 & $\ldots$ & 40 & $\ldots$ & $\ldots$ & 11 & $\ldots$ & 15 & $\ldots$ & $\ldots$ & 5 & 0.50 & 0.00 \\
\hline PV-ag001 & 11 & 3 & $\ldots$ & 6 & $\ldots$ & 5 & 12 & $\ldots$ & 21 & $\ldots$ & 18 & 6 & $\ldots$ & 8 & $\ldots$ & 6 & 0.50 & 0.00 \\
\hline
\end{tabular}

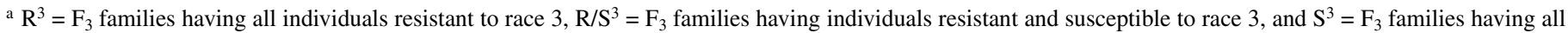
individuals susceptible to race $3 . \mathrm{K} / \mathrm{K}=$ homozygous for the Kaboon alleles of the corresponding marker, K/- = homozygous for the Kaboon alleles or heterozygous, $\mathrm{K} / \mathrm{M}=$ heterozygous, $\mathrm{M} /-=$ homozygous for the Michelite alleles or heterozygous, and $\mathrm{M} / \mathrm{M}=$ homozygous for the Michelite alleles. Linkage values are expressed as recombination fraction (RF) and $\log$ of the likelihood ration (LOD).

b Linkage group in which the marker is located. 
corresponding to parental Kaboon for the markers closely linked to cluster Co-1 (OF10 ${ }_{530}$ and AT003) and for the alleles corresponding to parental Michelite for the markers flanking the Co-3/9 cluster (OF10 $1100, \mathrm{SW} 12$, SB10, PV-ctt001, and SI19). It can be expected that, in this family, the complementary gene conferring resistance to race 31 located in cluster $\mathrm{Co}-1$ is present in homozygous condition, and the one located in cluster Co-3/9 is lacking. The $F_{3}$ family $F_{3}-105$ had the resistance spectrum $S^{31} S^{81}$ $\mathrm{R}^{3} \mathrm{R}^{7} \mathrm{R}^{19}$ and was homozygous for the alleles corresponding to parental Michelite for the markers closely linked to cluster $\mathrm{Co}-1$ $\left(\mathrm{OF} 10_{530}\right.$ and AT003) and for the alleles corresponding to parental Kaboon for the markers flanking the Co-3/9 cluster $\left(\mathrm{OF} 10_{1100}\right.$, SW12, SB10, PV-ctt001, and SI19). In this family, the opposite situation to that of $\mathrm{F}_{3}-64$ can be expected: the complementary gene conferring resistance to race 31 located in cluster Co-3/9 would be present in the homozygous condition whereas the one located in cluster $\mathrm{Co}-1$ would be lacking. Then, the offspring of the cross $\mathrm{F}_{3}-46 \times \mathrm{F}_{3}-105$ would be heterozygous for the two complementary genes conferring resistance to race 31 located in clusters $\mathrm{Co}-1$ and $\mathrm{Co}-3 / 9$, respectively, and would be resistant to this race. The results obtained confirmed this hypothesis. The offspring obtained by self-pollination of individual plants of families $F_{3}-64$ and $F_{3}-105$ were susceptible to race 31 , whereas the offspring obtained from crosses between such plants $\left(\mathrm{F}_{3}-64 \times\right.$ $\mathrm{F}_{3}$-105) were resistant to this race.

\section{DISCUSSION}

Our results indicate that resistance to the eight $C$. lindemuthianum races $3,7,19,31,81,449,453$, and 1545 , present in Kaboon, is determined by 13 different race-specific genes grouped in three clusters. One of these clusters, located in LG 1, corresponding to locus $\mathrm{Co}-1$, carries two dominant genes conferring specific resistance to races 81 and 1545, respectively, and a gene necessary (dominant complementary gene) for the specific resistance to race 31 . A second cluster, located in LG 4, corresponding to locus $\mathrm{Co}-3 / 9$, carries six dominant genes conferring specific resistance to races $3,7,19,449,453$, and 1545 , respectively, and the second dominant complementary gene for the specific resistance to race 31. A third cluster of unknown location, segregating independently from molecular markers linked to Co-2 (PV-ag001) (47), Co-4 (SC08) (48), and Co-5 (BM210 and Phs) (10), carries three dominant genes conferring specific resistance to races 449,453 , and 1545, respectively. Disease resistance loci in plants are frequently organized as clusters of genes, each one conferring resistance to a different pathogen or to a specific race of the same pathogen $(13,42,53,57)$. The results obtained in the present work agree with those obtained in other common bean genotypes $(10,50,51)$ and suggest that $\mathrm{Co}$ - loci, contrary to the previous assumption of being formed by single major genes conferring resistance to several anthracnose races (31), are also organized as clusters of race-specific resistance genes.

Among all described anthracnose resistance loci, Co-1 and, recently, the unmapped $C o-12$ and $C o-13$ genes, have been considered the only loci originating in the Andean gene pool $(23,31)$. However, these are not the only anthracnose resistance loci present in Andean materials. In previous works, Geffroy (19) and Geffroy et al. (22), using the Jalo EEP558 × BAT93 recombinant inbred line population, located Andean resistance genes (Co-x and $\mathrm{Co}-\mathrm{w})$ at the end of LG 1 (coinciding with $\mathrm{Co}-1$ ), and both Andean (Jalo EEP558) and Mesoamerican (BAT93) resistance specificities at LG 4 ( $\mathrm{Co}-y, \mathrm{Co}-z$, and $\mathrm{Co}-9)$, corresponding to the $\mathrm{Co}-3 / 9$ locus. They concluded that this locus existed prior to the separation of the two major gene pools of $P$. vulgaris. In agreement with the results of Geffroy et al. (22), Campa et al. (10) demonstrated that the Andean cultivar MDRK carries different anthracnose race-specific genes at both the Co- 1 and $\mathrm{Co}-3 / 9$ loci. The results obtained in this work provide additional evidence supporting the presence of Andean anthracnose resistance genes at these loci.

The resistance of Kaboon to anthracnose races 7 and 73 was studied by Melotto and Kelly (38). After inoculating the $\mathrm{F}_{2}$ populations MDRK $\times$ Kaboon and Cardinal $\times$ Kaboon (susceptible $\times$ resistant crosses, respectively) with race 7 , a segregation ratio of 3:1 R:S was observed in both cases, indicating that a single dominant gene in Kaboon confers resistance to race 7. After inoculating the $F_{2}$ population Cardinal $\times$ Kaboon (susceptible $\times$ resistant cross) with a mixture of races 7 and 73, the same 3:1 R:S ratio was observed, indicating that the same gene in Kaboon confers resistance to races 7 and 73. A lack of segregation was observed after inoculating the $\mathrm{F}_{2}$ population MDRK $\times$ Kaboon

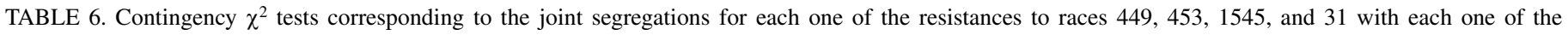
monogenic resistance to races $3,7,19$, and 81 and with each one of the different markers ${ }^{\mathrm{a}}$

\begin{tabular}{|c|c|c|c|c|c|c|c|c|c|}
\hline \multirow[b]{2}{*}{ Locus or marker } & \multirow[b]{2}{*}{ LG } & \multicolumn{2}{|c|}{ Race 449} & \multicolumn{2}{|c|}{ Race 453} & \multicolumn{2}{|c|}{ Race 1545} & \multicolumn{2}{|c|}{ Race 31} \\
\hline & & $\chi^{2}$ & $P$ & $\chi^{2}$ & $P$ & $\chi^{2}$ & $P$ & $\chi^{2}$ & $P$ \\
\hline Race 3 & 4 & 61.87 & $* *$ & 60.41 & $* *$ & 39.14 & $* *$ & 10.46 & $*$ \\
\hline Race 7 & 4 & 59.20 & $* *$ & 60.41 & $* *$ & 39.09 & $* *$ & 10.65 & $*$ \\
\hline Race 19 & 4 & 61.23 & $* *$ & 59.71 & $* *$ & 38.47 & $* *$ & 16.04 & $* *$ \\
\hline Race 81 & 1 & 4.76 & n.s. & 3.02 & n.s. & 20.78 & $* *$ & 28.13 & $* *$ \\
\hline $\mathrm{OF} 10_{530}$ & 1 & 2.68 & n.s. & 2.69 & n.s. & 15.35 & $* *$ & 8.32 & $*$ \\
\hline AT003 & 1 & 3.39 & n.s. & 2.30 & n.s. & 9.38 & n.s. & 15.70 & $* *$ \\
\hline BMd45-AIA & 1 & 3.56 & n.s. & 1.49 & n.s. & 3.25 & n.s. & 13.69 & $* *$ \\
\hline BM200 & 1 & 0.97 & n.s. & 0.48 & n.s. & 1.34 & n.s. & 2.45 & n.s. \\
\hline BM167 & 2 & 0.16 & n.s. & 0.12 & n.s. & 0.15 & n.s. & 3.11 & n.s. \\
\hline BM172 & 3 & 8.57 & n.s. & 8.07 & n.s. & 9.46 & n.s. & 2.16 & n.s. \\
\hline BMd26 & 4 & 2.62 & n.s. & 2.91 & n.s. & 1.19 & n.s. & 6.62 & n.s. \\
\hline ATA20 & 4 & 3.21 & n.s. & 2.99 & n.s. & 0.30 & n.s. & 3.98 & n.s. \\
\hline BM140 & 4 & 7.25 & n.s. & 7.12 & n.s. & 2.23 & n.s. & 24.21 & $* *$ \\
\hline $\mathrm{OF} 10_{1100}$ & 4 & 28.61 & $* *$ & 27.03 & $* *$ & 17.54 & $* *$ & 8.59 & $*$ \\
\hline SW12 & 4 & 26.40 & $* *$ & 30.08 & $* *$ & 14.75 & $* *$ & 8.79 & $*$ \\
\hline SB10 & 4 & 35.51 & $* *$ & 33.33 & $* *$ & 24.53 & $* *$ & 7.58 & $*$ \\
\hline PV-ctt001 & 4 & 43.67 & $* *$ & 41.77 & $* *$ & 36.56 & $* *$ & 10.29 & $*$ \\
\hline SI19 & 4 & 23.64 & $* *$ & 21.92 & $* *$ & 10.90 & $* *$ & 6.61 & $*$ \\
\hline BM210 & 7 & 5.55 & n.s. & 3.10 & n.s. & 2.66 & n.s. & 0.62 & n.s. \\
\hline Phs & 7 & 4.12 & n.s. & 3.89 & n.s. & 5.41 & n.s. & 2.17 & n.s. \\
\hline SC08 & 8 & 1.77 & n.s. & 1.47 & n.s. & 0.53 & n.s. & 0.66 & n.s. \\
\hline PV-ag001 & 11 & 5.36 & n.s. & 2.89 & n.s. & 1.04 & n.s. & 4.16 & n.s. \\
\hline
\end{tabular}

${ }^{\mathrm{a}} \mathrm{LG}=$ linkage group in which the locus or marker is located, n.s. $=$ not significant, $*$ indicates $0.05>P>0.01$, and $* *$ indicates $0.01>P$. 
(resistant $\times$ resistant cross) with race 73 . Under the assumption that $\mathrm{Co}-1$ was the only anthracnose resistance locus present in MDRK, Melotto and Kelly (36) concluded that resistance against races 7 and 73 in Kaboon is conferred by an allele of the Co-1 locus. In the present work, the gene conferring resistance to race 7 of Kaboon has been directly mapped at the $C o-3 / 9$ cluster, in LG 4. The results of Melotto and Kelly (38) could be reinterpreted by assuming that the genes conferring resistance to race 73 in MDRK and in Kaboon, respectively, are located at the Co-3/9 locus not at the $\mathrm{Co}-1$ locus. The presence of two anthracnose resistance genes against races 449 and 1545 at the Co-3/9 cluster in MDRK was demonstrated by Campa et al. (10). The lack of segregation of resistance to race 73 in the $F_{2}$ population Jalo EEP558 $\times$ MDRK (resistant $\times$ resistant cross), observed by Vallejo et al. (55), can also be interpreted under the assumption that resistance to this race is located at the Co-3/9 locus in both genotypes. Geffroy et al. (21) demonstrated the presence of several anthracnose resistance specificities at the Co-3/9 locus in Jalo EEP558. The confirmation of the Co-3/9 location of resistance to race 73 in MDRK is of great interest because new $\mathrm{Co}$ - genes have been described on some occasions $(3,23)$ based on the results of allelism tests in which it was assumed that resistance to race 73 in MDRK was due to the Co-1 gene.

The results of different segregation analyses for resistance to races $\beta$ (130), $\gamma$ (102), and $\Delta$ (23), carried out by Muhalet et al. (44), suggested that Kaboon carries two dominant complementary genes conferring resistance to race $\beta$, one dominant complementary gene to race $\gamma$ (a second complementary gene being present in the genotype Cornell 49242 as well as in the genotype Tuscola), and two dominant complementary genes conferring resistance to race $\Delta$. Also, the segregations $57: 7 \mathrm{R}: \mathrm{S}$ obtained by Melotto and Kelly (38) in the $F_{2}$ from the crosses Perry Marrow $(\mathrm{S}) \times$ Kaboon $(\mathrm{R})$ and Cardinal $(\mathrm{S}) \times$ Kaboon $(\mathrm{R})$ suggested that resistance to race 5 in Kaboon is conferred by three dominant independent genes, two of them having a complementary mode of action. The presence in common bean of anthracnose resistance genes with a complementary mode of action has been also suggested in other instances (31) but no attempts were made for mapping these genes, and their relationship with previously known $\mathrm{Co}$ - resistance genes was not established. The results obtained in this work confirm the presence in Kaboon of at least two anthracnose resistance genes with a complementary mode of action. One of these genes has been mapped at the Co-3/9 anthracnose resistance cluster in LG 4 and the other has been located at the Co- 1 anthracnose resistance cluster in LG 1 . Complementary resistance genes required for resistance have been described in common bean (against the bean rust pathogen Uromyces appendiculatus) (28), tomato (26,52), Arabidopsis (58), and barley (27).

The 1:8:7 R:R/S:S segregation observed in this work for resistance to a specific anthracnose race is evidence of the presence of two dominant, independent complementary loci being responsible for that anthracnose resistance. Nevertheless, the 1:2:1 R:R/S:S segregation found in other cases does not preclude the possibility for a two-gene system to be of general occurrence in the anthracnose resistance response in common bean. A segregation corresponding to a single gene $(1: 2: 1 \mathrm{R}: \mathrm{R} / \mathrm{S}: \mathrm{S})$ would be observed if the parental cultivars differed in only one of the two genes or, alternatively, if, although differing in the two genes, they are closely linked in the same cluster.

\section{ACKNOWLEDGMENTS}

This work was supported by grants RTA2005-00115-C02-01 from the Ministerio de Educación y Ciencia, Spain. Anthracnose races 7, 31, 81, 453,449 , and 1545 were kindly provided by James D. Kelly, Michigan State University.

\section{LITERATURE CITED}

1. Adam-Blondon, A. F., Sévignac, M., Bannerot, H., and Dron, M. 1994. SCAR, RAPD and RFLP markers linked to a dominant gene (Are) conferring resistance to anthracnose. Theor. Appl. Genet. 88:865-870.

2. Alzate-Marin, A. L., Baia, G. S., Junior, T. J. P., Carbalho, G. A., Barros, E. G., and Moreira, M. A. 1997. Inheritance of anthracnose resistance in common bean differential cultivar AB136. Plant Dis. 81:996-998.

3. Alzate-Marin, A. L., Costa, M. R., Arruda, K. M., Gonçalves de Barros, E., and Moreira, M. A. 2003. Characterization of the anthracnose resistance gene present in Ouro Negro (Honduras 35) common bean cultivar. Euphytica 133:165-169.

4. Alzate-Marin, A. L., Souza, K. A., Morais Silva, M. G., Oliveira, E. J., Moreira, M. A., and Barros, E. G. 2007. Genetic characterization of anthracnose resistance genes $\mathrm{Co}_{-} 4^{3}$ and $\mathrm{Co}-9$ in common bean cultivar tlalnepantla 64 (PI 207262). Euphytica 154:1-8.

5. Balardin, R. S., Jarros, A. M., and Kelly, J. D. 1997. Virulence and molecular diversity in Colletotrichum lindemuthianum from South, Central, and North America. Phytopathology 87:1184-1191.

6. Bannerot, H. 1965. Résults de l'infection d'une collection de haricots par six races physiologiques d'anthracnose. Ann. Amelior. Plant. 15:201-222.

7. Barrus, M. F. 1915. An anthracnose-resistant red kidney bean. Phytopathology 5:303-311.

8. Blair, M. W., Buendía, H. F., Giraldo, M. C., Métais, I., and Peltier, D. 2008. Characterization of AT-rich microsatellites in common bean (Phaseolus vulgaris L.). Theor. Appl. Genet. 118:91-103.

9. Blair, M. W., Pedraza, F., Buendia, H. F., Gaitán-Solís, E., Beebe, S. E., Gepts, P., and Tohme, J. 2003. Development of a genome-wide anchored microsatellite map for common bean (Phaseolus vulgaris L.). Theor. Appl. Genet. 107:1362-1374.

10. Campa, A., Giraldez, R., and Ferreira, J. J. 2009. Genetic dissection of the resistance to nine different anthracnose races in the common bean differential cultivars MDRK and TU. Theor. Appl. Genet. 119:1-11.

11. Campa, A., Pérez Vega, E., Giraldez, R., and Ferreira, J. J. 2007. Inheritance of race-specific resistance to anthracnose in the differential cultivar AB136. Annu. Rep. Bean Improv. Coop. 50:87-88.

12. Cardenas, F., Adams, M. W., and Andersen, A. 1964. The genetic system for reaction of field beans (Phaseolus vulgaris L.) to infection by three physiologic races of Colletotrichum lindemuthianum. Euphytica 13:178186.

13. Crute, I. R., and Pink, D. A. C. 1996. Genetics and utilization of pathogen resistance in plants. Plant Cell 8:1747-1755.

14. David, P., Chen, N. W. G., Pedrosa-Harand, A., Thareau, V., Sévignac, M., Cannon, S. B., Debouck, D., Langin, T., and Geffroy, V. 2009. A nomadic subtelomeric disease resistance gene cluster in common bean. Plant Physiol. 151:1048-1065.

15. Ferreira, J. J., Campa, A., Pérez-Vega, E., and Giraldez, R. 2008. Reaction of a bean germplasm collection against five races of Colletotrichum lindemuthianum identified in northern Spain and implications for breeding. Plant Dis. 92:705-708.

16. Fouilloux, G. 1976. L'anthracnose du haricot (Colletotrichum lindemuthianum, Sacc et Magn): nouvelles sources de résistance et nouvelles races physiologiques. Ann. Amelior. Plant. 26:443-453.

17. Fourie, D., Miklas, P. N., and Ariyarathne, H. M. 2004. Genes conditioning halo blight resistance to races 1,7 , and 9 occur in a tight cluster. Annu. Rep. Bean Improv. Coop. 47:103-104.

18. Freyre, R., Skroch, P. W., Geffroy, V., Adam-Blondon, A. F., Shirmohamadali, A., Johnson, W. C., Llaca, V., Nodari, R. O., Pereira, P. A., Tsai, S. M., Tohme, J., Dron, M., Nienhuis, J., Vallejos, C. E., and Gepts, P. 1998. Towards an integrated linkage map of common bean. 4 . Development of a core linkage map and alignment of RFLP maps. Theor. Appl. Genet. 97:847-856.

19. Geffroy, V. 1997. Dissection génétique de la résistance à Colletotrichum lindemuthianum, agent de l'anthracnose, chez deux génotypes représentatifs des pools géniques de Phaseolus vulgaris. Ph.D. thesis, Inst. Natl. Agron. Paris-Grignon.

20. Geffroy, V., Macadré, C., David, P., Pedrosa-Harand, A., Sévignac, M., Dauga, C., and Langin, T. 2009. Molecular analysis of a large subtelomeric nucleotidebinding-site-leucine-rich-repeat family in two representative genotypes of the major gene pools of Phaseolus vulgaris. Genetics 181:405-419.

21. Geffroy, V., Sévignac, M., Billant, P., Dron, M., and Langin, T. 2008. Resistance to Colletotrichum lindemuthianum in Phaseolus vulgaris: a case study for mapping two independent genes. Theor. Appl. Genet. 116:407-415.

22. Geffroy, V., Sicard, D., de Oliveira, J. C. F., Sévignac, M., Cohen, S., Gepts, P., Neema, C., Langin, T., and Dron, M. 1999. Identification of an ancestral resistance gene cluster involved in the coevolution process between Phaseolus vulgaris and its fungal pathogen Colletotrichum lindemuthianum. Mol. Plant-Microbe Interact. 12:774-784. 
23. Gonçalves-Vidigal, M. C., Filho, P. S. V., Medeiros, A. F., and PastorCorrales, M. A. 2009. Common bean landrace Jalo Listras Pretas is the source of a new Andean anthracnose resistance gene. Crop Sci. 49:133138.

24. Gonçalves-Vidigal, M. C., and Kelly, J. D. 2006. Inheritance of anthracnose resistance in the common bean cultivar Widusa. Euphytica 151:411-419.

25. Gonçalves-Vidigal, M. C., Silva, C. R., Filho, P. S. V., Gonela, A., and Kvitschal, M. V. 2007. Allelic relationships of anthracnose (Colletotrichum lindemuthianum) resistance in the common bean (Phaseolus vulgaris L.) cultivar Michelite and the proposal of a new anthracnose resistance gene, Co-11. Genet. Mol. Biol. 30:589-593.

26. Hammond-Kosack, K. E., Jones, D. A., and Jones, J. D. G. 1994. Identification of two genes required in tomato for full Cf-9 dependent resistance to Cladosporium fulvum. Plant Cell 6:361-374.

27. Jøregensen, J. H. 1988. Genetic analysis of barley mutants with modifications of powdery mildew resistance gene $\mathrm{Ml}$-al2. Genome 30:129-132.

28. Kalavacharla, V., Stavely, J. R., Myers, J. R., and McClean, P. E. 2000. $\mathrm{Crg}$, a gene required for $\mathrm{Ur}$-3-mediated rust resistance in common bean, maps to a resistance gene analog cluster. Mol. Plant-Microbe Interact. $13: 1237-1242$

29. Kami, J., Velasquez, V. B., Debouck, D. G., and Gepts, P. 1995. Identification of presumed ancestral DNA sequences of phaseolin in Phaseolus vulgaris. Proc. Natl. Acad. Sci. USA 92:1101-1104.

30. Kelly, J. D., Gepts, P., Miklas, P. N., and Coyne, D. P. 2003. Tagging and mapping of genes and QTL and molecular marker-assisted selection for traits of economic importance in bean and cowpea. Field Crop Res. 82:135-154.

31. Kelly, J. D., and Vallejo, V. A. 2004. A comprehensive review of the major genes conditioning resistance to anthracnose in common bean. HortScience 39:1196-1207.

32. Lander, E. S., Green, P., Abrahamson, J., Barlow, A., Daly, M. J., Lincoln, S. E., and Newburg, L. 1987. MAPMAKER: an interactive computer package for constructing primary genetic linkage maps of experimental and natural populations. Genomics 1:174-181.

33. Mahuku, G. S., and Riascos, J. J. 2004. Virulence and molecular diversity within Colletotrichum lindemuthianum isolates from Andean and Mesoamerican bean varieties and regions. Eur. J. Plant Pathol. 110:253263.

34. Mastenbroek, C. 1960. A breeding programme for resistance to anthracnose in dry shell haricot beans, based on a new gene. Euphytica 9:177-184.

35. Melotto, M., Balardin, R. S., and Kelly, J. D. 2000. Host-pathogen interaction and variability of Colletotrichum lindemuthianum. Pages 346361 in: Colletotrichum Host Specificity, Pathology, and Host-Pathogen Interaction. D. Prusky, S. Freeman, and M. B. Dickman, eds. American Phytopathological Society Press St. Paul, MN.

36. Melotto, M., Coelho, M. F., Pedrosa-Harand, A., Kelly, J. D., and Camargo, L. E. A. 2004. The anthracnose resistance locus $\mathrm{Co}-4$ of common bean is located on chromosome 3 and contains putative disease resistance-related genes. Theor. Appl. Genet. 109:690-699.

37. Melotto, M., and Kelly, J. D. 1998. SCAR markers linked to major disease resistance genes in common bean. Annu. Rep. Bean Improv. Coop. 41:64-65.

38. Melotto, M., and Kelly, J. D. 2000. An allelic series at the Co-1 locus conditioning resistance to anthracnose in common bean of Andean origin. Euphytica 116:143-149.

39. Méndez de Vigo, B. 2001. Mapa genético de Phaseolus vulgaris L. y resistencia a antracnosis en faba granja asturiana. Ph.D. thesis, University of Oviedo, Spain.

40. Méndez-Vigo, B., Rodríguez-Suárez, C., Pañeda, A., Ferreira, J. J., and Giraldez, R. 2005. Molecular markers and allelic relationships of anthracnose resistance gene cluster B4 in common bean. Euphytica 141:237-245.

41. Menezes, J. R., and Dianese, J. C. 1988. Race characterization of Brazilian isolates of Colletotrichum lindemuthianum and detection of resistance to anthracnose in Phaseolus vulgaris L. Phytopathology 78:650655 .

42. Michelmore, R. W., and Meyers B. C. 1998. Clusters of resistance genes in plants evolve by divergent selection and a birth-and-death process.
Genome Res. 8:1113-1130.

43. Miklas, P. N., Delorme, R., Stone, V., Daly, M. J., Stavely, J. R., Steadman, J. R., Basset, M. J., and Beaver, J. S. 2000. Bacterial, fungal, virus disease loci mapped in a recombinant inbred common bean population ("Dorado/XAN 176"). J. Am. Soc. Hortic. Sci. 125:476-481.

44. Muhalet, C. S., Adams, M. W., Saettler, A. W., and Ghaderi, A. 1981 Genetic system for the reaction of field beans to beta, gamma, and delta races of Colletotrichum lindemuthianum. J. Am. Soc. Hortic. Sci. 106:601-604.

45. Pañeda, A., Rodríguez-Suárez, C., Campa, A., Ferreira, J. J., and Giraldez, R. 2008. Molecular markers linked to the fin gene controlling determinate growth habit in common bean. Euphytica 162:241-248.

46. Pastor-Corrales, M. A. 1991. Estandarización de variedades diferenciales y de designación de razas de Colletotrichum lindemuthianum. (Abstr.) Phytopathology 81:694.

47. Pérez-Vega, E., Pañeda, A., Rodríguez-Suárez, C., Campa, A., Giraldez, R., and Ferreira, J. J. 2010. Mapping of QTLs for morpho-agronomic and seed quality traits in a RIL population of common bean (Phaseolus vulgaris L.). Theor. Appl. Genet. 120:1367-1380.

48. Queiroz, V. T., Sousa, C. S., Costa, M. R., Sanglad, D. A., Arruda, K. M A., Souza, T. L. P. O., Ragagnin, V. A., Barros, E. G., and Moreira, M. A. 2004. Development of SCAR markers linked to common bean anthracnose resistance genes $\mathrm{Co}-4$ and $C o-6$. Annu. Rep. Bean Improv. Coop. 47:249-250.

49. Rodríguez-Guerra, R., Ramírez-Rueda, M. T., Martínez de la Vega, O., and Simpson, J. 2003. Variation in genotype, pathotype and anastomosis groups of Colletotrichum lindemuthianum isolates from Mexico. Plant Pathol. 52:228-235.

50. Rodríguez-Suárez, C., Ferreira, J. J., Campa, A., Pañeda, A., and Giraldez, R. 2008. Molecular mapping and intra-cluster recombination between anthracnose race-specific resistance genes in the common bean differential cultivars Mexico 222 and Widusa. Theor. Appl. Genet. 116:807-814.

51. Rodríguez-Suárez, C., Méndez-Vigo, B., Pañeda, A., Ferreira, J. J., and Giraldez, R. 2007. A genetic linkage map of Phaseolus vulgaris L. and localization of genes for specific resistance to six races of anthracnose (Colletotrichum lindemuthianum). Theor. Appl. Genet. 114:713-722.

52. Salmeron, J. M., Barker, S. J., Carland, F. M., Mehta, A. Y., and Staskawicz, B. J. 1994. Two mutants altered in bacterial disease resistance provide evidence for a new locus controlling pathogen recognition. Plant Cell 6:511-520.

53. Sharma, K. D., Winter, P., Kahl, G., and Muehlbauer, J. 2004. Molecular mapping of Fusarium oxysporum f. sp. Ciceris race 3 resistance gene in chickpea. Theor. Appl. Genet. 108:1243-1248.

54. Vallejo, V., and Kelly, J. D. 2005. Unexpected resistance genes for anthracnose uncovered. Annu. Rep. Bean Improv. Coop. 48:74-75.

55. Vallejo, V. A., Awale, H. E., and Kelly, J. D. 2003. Characterization of the anthracnose resistance in the Andean bean cultivar Jalo EEP558. Annu. Rep. Bean Improv. Coop. 46-179-180.

56. van Schoonhoven, A., and Pastor-Corrales, M. A. 1987. Standard System for the Evaluation of Bean Germplasm. CIAT, Cali, Colombia.

57. Vear, F., Gentzbittel, L., Philippon, J., Mouzeyar, S., Mestries, E., Roeckel-Drevet, P., Tourvieille de Labrouhe, D., and Nicolas, P. 1997. The genetics of resistance to five races of downy mildew (Plasmopara halstedii) in sunflower (Helianthus annuus L.). Theor. Appl. Genet. 95:584-589.

58. Warren, R. F., Merritt, P. M., Holub, E., and Innes, R. W. 1999. Identification of three putative signal transduction genes involved in $\mathrm{R}$ gene specified disease resistance in Arabidopsis. Genetics 152:401-412.

59. Young, R. A., and Kelly, J. D. 1996. Characterization of the genetic resistance to Colletotrichum lindemuthianum in common bean differential cultivars. Plant Dis. 80:650-654.

60. Young, R. A., and Kelly, J. D. 1997. RAPD markers linked to three major anthracnose resistance genes in common bean. Crop Sci. 37:940-946.

61. Young, R. A., Melotto, M., Nodari, R. O., and Kelly, J. D. 1998. Markerassisted dissection of the oligogenic anthracnose resistance in the common bean cultivar, 'G2333'. Theor. Appl. Genet. 96:87-94.

62. Yu, K., Park, S. J., Poysa, V., and Gepts, P. 2000. Integration of simple sequence repeat (SSR) markers into a molecular linkage map of common bean (Phaseolus vulgaris L.). J. Hered. 91:429-434. 